\title{
Formation of an unexpected 3,3-diphenyl-3H-indazole through a facile intramolecular [2 + 3] cycloaddition of the diazo intermediate
}

\author{
Andrew T. King ${ }^{1}$, Hugh G. Hiscocks ${ }^{1}$, Lidia Matesic ${ }^{1,2}$, Mohan Bhadbhade ${ }^{3}$, \\ Roger Bishop ${ }^{4}$ and Alison T. Ung ${ }^{* 1}$
}

\author{
Full Research Paper \\ Address: \\ 1School of Mathematical and Physical Sciences, University of \\ Technology Sydney, PO Box 123, Broadway, NSW, 2007, Australia, \\ ${ }^{2}$ Australian Nuclear Science and Technology Organisation, Locked \\ Bag 2001, Kirrawee DC, NSW, 2232, Australia, ${ }^{3}$ Mark Wainwright \\ Analytical Centre, University of New South Wales, Sydney, NSW, \\ 2052, Australia, and ${ }^{4}$ School of Chemistry, University of New South \\ Wales, Sydney, NSW, 2052, Australia \\ Email: \\ Alison T. Ung ${ }^{*}$ - Alison.Ung@uts.edu.au \\ * Corresponding author \\ Keywords: \\ Ar-H $\cdots \mathrm{H}$-Ar contact; [2 + 3] cycloaddition; diazo; $3 \mathrm{H}$-indazole; $\mathrm{X}$-ray \\ structure \\ Beilstein J. Org. Chem. 2019, 15, 1347-1354. \\ doi:10.3762/bjoc. 15.134 \\ Received: 18 March 2019 \\ Accepted: 07 June 2019 \\ Published: 19 June 2019 \\ Associate Editor: J. Aubé \\ (C) 2019 King et al.; licensee Beilstein-Institut. \\ License and terms: see end of document.
}

\begin{abstract}
The one-pot reaction of 2,6-bis(diphenylmethyl)-4-methoxyaniline with tert-butylnitrite, BTEAC and DABSO in the presence of $\mathrm{CuCl}_{2}$ provided an unexpected $3 \mathrm{H}$-indazole product $\mathbf{8}$. The structure of the compound was determined by HRMS, IR, NMR and further confirmed by single crystal X-ray crystallography. The compound crystallises in the triclinic $P-1$ space group, with unit cell parameters $a=9.2107$ (4), $b=10.0413$ (5), $c=14.4363$ (6) $\AA, \alpha=78.183$ (2), $\beta=87.625$ (2), $\gamma=71.975$ (2) ${ }^{\circ}$. The formation of 8 proceeded through a facile intramolecular [2+3] cycloaddition of the diazo intermediate $\mathbf{9}$. The molecules of $\mathbf{8}$ are organised by edge-face $\mathrm{Ar}-\mathrm{H} \cdots \pi$, face-face $\pi \cdots \pi$, and bifurcated $\mathrm{OCH}_{2}-\mathrm{H} \cdots \mathrm{N}$ interactions. In addition to these, there are Ar-H $\cdots \mathrm{H}-\mathrm{Ar}$ close contacts, (edge-edge and surrounding inversion centres) arranged as infinite tapes along the $a$ direction.
\end{abstract}

\section{Introduction}

The use of sulfonyl fluorides in biological applications has been on the increase as evidenced by the number of recent publications [1-3]. One potential application of sulfonyl fluorides is as an ${ }^{18} \mathrm{~F}$-radiolabelled synthon that can be conjugated to macromolecules and used to image cancer and other diseases in the body. Synthons are becoming more prevalent in imaging modalities like positron emission tomography (PET) as there is a greater need to further investigate lesions, and disease tissues on the molecular level. However, issues with the stability of sulfonyl fluorides have been reported in the literature [4,5]. 
Stability and radiochemical improvements were investigated by Matesic et al. [5]. For instance, electron-donating ${ }^{18} \mathrm{~F}$-arylsulfonyl fluoride $\mathbf{1}$ was $>98 \%$ stable in the buffer at $3 \mathrm{~h}$, while the electron-withdrawing compound 2 was only $8 \%$ stable [5] (Figure 1). The more sterically hindered ${ }^{18} \mathrm{~F}$-arylsulfonyl fluoride 3 was $95 \%$ intact in rat plasma after $120 \mathrm{~min}$ at $37{ }^{\circ} \mathrm{C}$ [5] This indicated that the combination of electron-donating effects and steric hindrance of isopropyl groups provide greater stability to a sulfur-fluorine bond than groups that can only provide the steric hindrance in the molecule [6].<smiles>CC(=O)Nc1ccc(S(=O)(=O)[O-])cc1</smiles><smiles>O=[N+]([O-])c1ccc(S(=O)(=O)[O-])cc1</smiles><smiles>CC(C)c1cc(C(C)C)c(S(=O)(=O)[O-])c(C(C)C)c1</smiles><smiles>COc1cc(C(c2ccccc2)c2ccccc2)c(S(=O)(=O)[O-])c(C(c2ccccc2)c2ccccc2)c1</smiles>

Figure 1: Examples of ${ }^{18} \mathrm{~F}$-radiolabelled arylsulfonyl fluorides containing electron-donating 1 , electron-withdrawing 2 , and sterically bulky groups 3 [5] and 4.

To further investigate the stability of ${ }^{18} \mathrm{~F}$-sulfonyl fluorides, the sterically hindered compound $\mathbf{4}$ was selected with enough steric bulk in the 2,6-position. The initial chlorosulfonylation reaction was performed using 1,4-diazabicyclo[2.2.2] octane bis(sulfur dioxide) adduct (DABSO) as a source of sulfur dioxide. DABSO was selected as it would provide a facile method and is a safer alternative to sulfur dioxide gas [7-10]. The target molecule 4 was envisaged via the diazonium salt of 5 [11] and $\mathbf{6}$ and was a modification of the microfluidic flow reaction reported by Malet-Sanz et al. [12] (Scheme 1).

Herein, we report the unexpected product derived from $\mathbf{5}$ under the reaction conditions described in Scheme 1. The unusual crystal packing present in this $3 H$-indazole product was also analysed.

\section{Results and Discussion}

The one-pot reaction of compound 5 with tert-BuONO and DABSO in the presence of benzyltriethylammonium chloride (BTEAC) and $\mathrm{CuCl}_{2}$ gave a crude product which was purified by crystallisation from dichloromethane/hexane to give a pale yellow crystalline material in $27 \%$ yield. HRMS-ESI analysis produced $[\mathrm{M}+\mathrm{H}]^{+} \mathrm{m} / \mathrm{z} 467.2126$ corresponding to the formula of $\mathrm{C}_{33} \mathrm{H}_{27} \mathrm{~N}_{2} \mathrm{O}$. Considering that the expected mass of the sulfonyl chloride 6 was $\mathrm{m} / \mathrm{z} 539.1403$ with the corresponding formula of $\mathrm{C}_{33} \mathrm{H}_{28} \mathrm{ClO}_{3} \mathrm{~S}$, it was concluded that 6 did not form. It was initially thought that the product was the diazonium intermediate 7 (Figure 2), as it was expected from the reaction conditions and the HRMS analysis of diazonium ion 7 in the form of $[\mathrm{M}]^{+}$was $\mathrm{C}_{33} \mathrm{H}_{27} \mathrm{~N}_{2} \mathrm{O}^{+}$.<smiles>COc1cc(C(c2ccccc2)c2ccccc2)c([N+]#N)c(C(c2ccccc2)c2ccccc2)c1</smiles><smiles>COc1cc(C(c2ccccc2)c2ccccc2)c2c(c1)C(c1ccccc1)(c1ccccc1)N=N2</smiles>

Figure 2: Possible compounds with the molecular formula $\mathrm{C}_{33} \mathrm{H}_{26} \mathrm{~N}_{2} \mathrm{O}$ (structure 7 contains 27 hydrogen atoms).

\section{Spectroscopy analysis}

A close analysis of the ${ }^{1} \mathrm{H}$ NMR spectrum revealed the nonsymmetrical substitution of the aromatic core. Two aromatic protons appeared as two doublets $(J=2 \mathrm{~Hz})$ at 6.92 and $6.67 \mathrm{ppm}$, respectively. Furthermore, the spectrum showed only one benzylic proton, as a singlet at $6.82 \mathrm{ppm} .{ }^{13} \mathrm{C}$ NMR and HSQC showed tertiary and quaternary resonances at 51.3 and $101.5 \mathrm{ppm}$, respectively. The first resonance is indicative of $\mathrm{HC}(\mathrm{Ph})_{2}$, while the one at $101.5 \mathrm{ppm}$ is more likely to be the 3,3-diphenyl-substituted carbon of the indazole ring. The ambiguity was overcome through the X-ray structural analysis of the compound. The single crystals were easily obtained by recrystallisation from $\mathrm{CH}_{2} \mathrm{Cl}_{2}$. 


\section{Crystal structure analysis}

The X-ray crystal analysis revealed that the product was not the diazonium intermediate $\mathbf{7}$, but rather the compound $\mathbf{8}$ containing the 3,3-diphenyl-3H-indazole core structure. The crystals were found to be triclinic, $P-1$ space group with cell constants $a=9.2107(4), b=10.0413(5), c=14.4363(6) \AA, \alpha=78.183(2)$, $\beta=87.625(2), \gamma=71.975(2)^{\circ}$. The structure of 8 and the atomlabelling scheme are presented in Figure 3. The crystal and refinement data are given in Table 1 . The $3 H$-indazole 8 $(-\mathrm{N}=\mathrm{N}-\mathrm{CRR}-)$ has a break in its conjugation at the $\mathrm{sp}^{3}$ carbon atom when it is compared to the $1 H$-indazole isomer $-\mathrm{NH}-\mathrm{N}=\mathrm{CH}-$ that is fully conjugated with the benzo group. Therefore, the $3 H$-indazole isomer is higher in energy and thus much less common. The bond lengths within this $3 H$-indazole ring structure confirm the evidence for $\mathrm{sp}^{2} \mathrm{~N}=\mathrm{N}$. The $\mathrm{N} 1-\mathrm{C} 1$ and N2-C9 distances are 1.426(2) $\AA$ and 1.530(2) $\AA$. The $\mathrm{N} 1=\mathrm{N} 2$ length was found to be $1.266(2) \AA$, a value that agrees with literature reports [13].

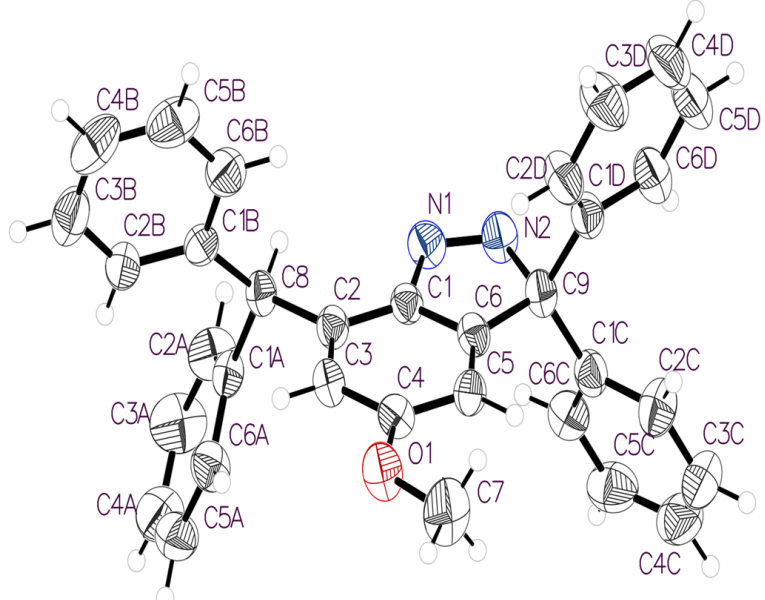

Figure 3: ORTEP view of the molecule 8 showing the atom labelling (ellipsoids are drawn at $50 \%$ probability level).

The 3,3-diphenyl-3H-indazole core of $\mathbf{8}$ carries both benzhydryl and germinal diphenyl groups. These aromatic substituents make significantly different intermolecular contacts in the crystal. The phenyl rings of the former $(\mathrm{C} 1 \mathrm{~A}$ to $\mathrm{C} 6 \mathrm{~A}$, and $\mathrm{C} 1 \mathrm{~B}$ to $\mathrm{C} 6 \mathrm{~B})$ make complementary $\mathrm{C}-\mathrm{H} \cdots \pi$ interactions with the related molecule across a centre of inversion. Hydrogen atoms $\mathrm{C} 2 \mathrm{~A}-\mathrm{H} 2 \mathrm{~A}$ and $\mathrm{C} 3 \mathrm{~A}-\mathrm{H} 3 \mathrm{~A}$ make an almost perpendicular approach to ring $\mathrm{B}$ at $\mathrm{C} 2 \mathrm{~B}$ and $\mathrm{C} 6 \mathrm{~B}$, respectively: $\mathrm{H} 2 \mathrm{~A} \cdots \mathrm{C} 2 \mathrm{~B}=$ $3.04 \AA$ and $\mathrm{H} 3 \mathrm{~A} \cdots \mathrm{C} 6 \mathrm{~B}=2.96 \AA$ (Figure 4a). One of the gemdiphenyl rings ( $\mathrm{C} 1 \mathrm{C}$ to $\mathrm{C} 6 \mathrm{C}$ ) also employs $\mathrm{C}-\mathrm{H} \cdots \pi$ interactions across a centre of inversion. Its partner is, however, the aromatic ring of the core ( $\mathrm{C} 1$ to $\mathrm{C} 6$ ). Thus, the hydrogens $\mathrm{C} 5 \mathrm{C}-\mathrm{H} 5 \mathrm{C}$ and $\mathrm{C} 4 \mathrm{C}-\mathrm{H} 4 \mathrm{C}$ make nearly perpendicular approaches to atoms $\mathrm{C} 5$ and $\mathrm{C} 3$, respectively: $\mathrm{H} 5 \mathrm{C} \cdots \mathrm{C} 5=2.95 \AA$ and $\mathrm{H} 4 \mathrm{C} \cdots \mathrm{C} 3=$

\begin{tabular}{|c|c|}
\hline \multicolumn{2}{|l|}{ crystal data } \\
\hline chemical formula & $\mathrm{C}_{33} \mathrm{H}_{26} \mathrm{~N}_{2} \mathrm{O}$ \\
\hline$M_{\mathrm{r}}$ & 466.56 \\
\hline crystal system, space group & triclinic, $P-1$ \\
\hline temperature $(\mathrm{K})$ & 150 \\
\hline$a, b, c(\AA)$ & $\begin{array}{l}9.2107(4), 10.0413(5) \\
14.4363(6)\end{array}$ \\
\hline$\alpha, \beta, \gamma\left({ }^{\circ}\right)$ & $\begin{array}{l}78.183(2), 87.625(2) \\
71.975(2)\end{array}$ \\
\hline$V\left(\AA^{3}\right)$ & $1242.40(10)$ \\
\hline$z$ & 2 \\
\hline radiation type & Mo K $\alpha$ \\
\hline$\mu\left(\mathrm{mm}^{-1}\right)$ & 0.08 \\
\hline crystal size (mm) & $0.22 \times 0.19 \times 0.11$ \\
\hline
\end{tabular}

\begin{tabular}{|c|c|}
\hline \multicolumn{2}{|l|}{ data collection } \\
\hline diffractometer & Bruker APEX-II CCD \\
\hline absorption correction & - \\
\hline $\begin{array}{l}\text { no. of measured, independent } \\
\text { and observed }[I>2 \sigma(I)] \\
\text { reflections }\end{array}$ & $40887,5423,4236$ \\
\hline$R_{\text {int }}$ & 0.039 \\
\hline$(\sin \theta / \lambda)_{\max }\left(\AA^{-1}\right)$ & 0.640 \\
\hline \multicolumn{2}{|l|}{ refinement } \\
\hline$R\left[F^{2}>2 \sigma\left(F^{2}\right)\right], w R\left(F^{2}\right), S$ & $0.054,0.157,1.04$ \\
\hline no. of reflections & 5423 \\
\hline no. of parameters & 326 \\
\hline $\mathrm{H}$-atom treatment & $\begin{array}{l}\mathrm{H} \text {-atom parameters } \\
\text { constrained }\end{array}$ \\
\hline$\Delta \rho_{\max }, \Delta \rho_{\min }\left(\mathrm{e} \AA^{-3}\right)$ & $0.51,-0.20$ \\
\hline CCDC deposition number & 1902859 \\
\hline
\end{tabular}

$3.08 \AA$. This phenyl ring also participates in a slipped $\pi \cdots \pi$ contact with its inversion-related counterpart: C6C … C5C $=3.50 \AA$ (Figure 4b).

The C4 methoxy and the heterocyclic diazo functionality of $\mathbf{8}$ are linked through an interesting arrangement along the $b$ axis that can be described either as a $\mathrm{OCH}_{2}-\mathrm{H} \cdots \pi(\mathrm{N}=\mathrm{N})$ or as a bifurcated $\mathrm{N} \cdots \mathrm{H}\left(\mathrm{CH}_{2} \mathrm{O}\right) \cdots \mathrm{N}$ interaction. This motif is close to symmetrical with $\mathrm{H} \cdots \mathrm{N}$ distances of $\mathrm{C} 7-\mathrm{H} 7 \mathrm{~A} \cdots \mathrm{N} 1=2.82 \AA$ and C7-H7A $\cdots \mathrm{N} 2=2.92 \AA$. The second of the gem-diphenyl rings (C1D to C6D) surrounds an inversion centre along with its counterpart through a cycle of two C4D-H4D $\cdots$ H5D-C5D contacts. Four molecules of $\mathbf{8}$, involving two $\mathrm{C}-\mathrm{H} \cdots \mathrm{N}$ and two cyclic $\mathrm{H} \cdots \mathrm{H}$ motifs, surround another inversion centre (Figure 5a). Consideration of additional molecules reveals a stepladder assembly along $b$, in which the $\mathrm{C}-\mathrm{H} \cdots \mathrm{N}$ interactions form the side rails and the cyclic $\mathrm{H} \cdots \mathrm{H}$ motifs the rungs (Figure 5b). 


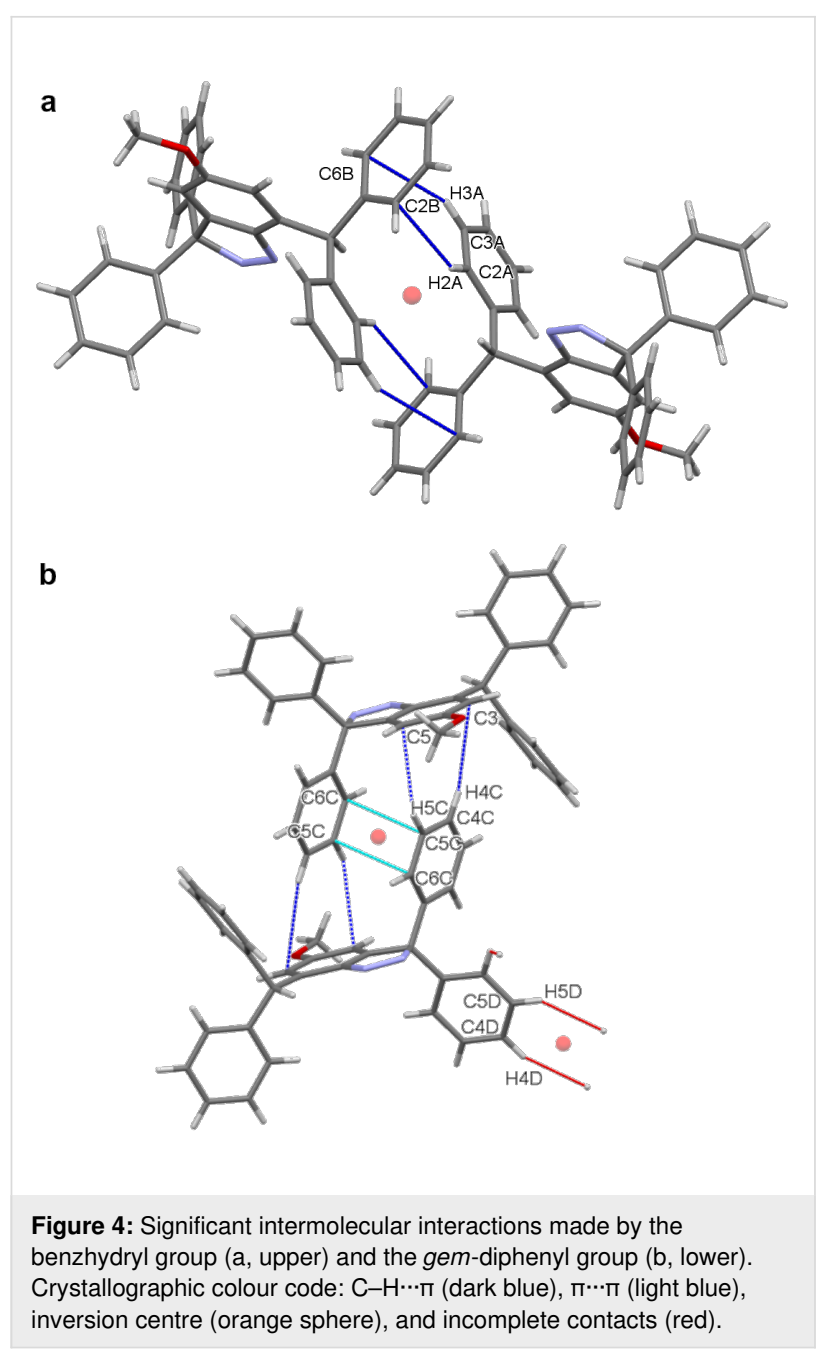

As well as the centrosymmetric cycle of C4D-H4D $\cdots H 5 D-C 5 D$ contacts $(\mathrm{H} \cdots \mathrm{H}=2.48 \AA)$ there is also a linear C6D-H6D $\cdots$ H6D-C6D close contact $(\mathrm{H} \cdots \mathrm{H}=2.37 \AA)$ around a further inversion centre. These two motifs alternate along the $a$ axis to produce infinite hydrocarbon tapes with inversion centres separated by $a / 2$ (Figure 6).

The molecular structure of $\mathbf{8}$ precludes Pauling-type hydrogen bonding, and therefore weaker attractions must be used in the crystal packing. Its interaction between the methoxy and diazo functionalities is uncommon, though entirely reasonable in the context of weak hydrogen bonding [14]. The presence of close $\mathrm{C}-\mathrm{H} \cdots \mathrm{H}-\mathrm{C}$ contacts in this structure was, however, unexpected and required careful consideration. First, one of us has reported previously a short $\mathrm{C}-\mathrm{H} \cdots \mathrm{H}-\mathrm{C}$ contact in another structure [15]. This was a linear centrosymmetric motif formed by $\mathrm{Ar}-\mathrm{H}$ $(\mathrm{H} \cdots \mathrm{H}=2.35 \AA)$ and is directly analogous in structure to the linear example $(2.37 \AA)$ found here. Both distances are less than the van der Waals (VDW) separation of $2.40 \AA$ [16]. The new cyclic example is slightly longer $(2.48 \AA$ ), but well under the

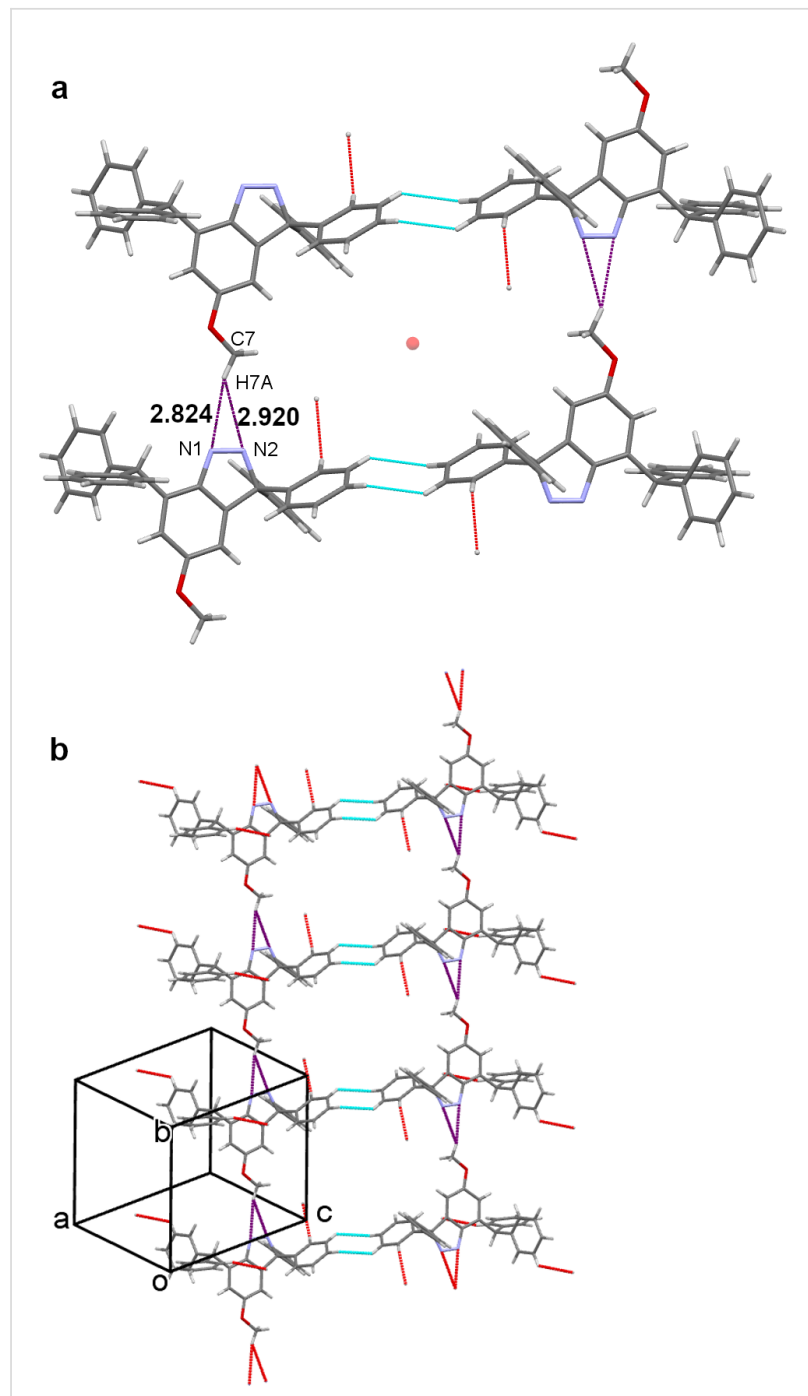

Figure 5: Relationship of the $\mathrm{C}-\mathrm{H} \cdots \mathrm{N}$ and cyclic $\mathrm{C}-\mathrm{H} \cdots \mathrm{H}-\mathrm{C}$ contacts in the crystal structure of $\mathbf{8}$. The centrosymmetric array of four molecules (5a, upper) and a stepladder association of eight molecules $(\mathbf{5 b}$, lower). Crystallographic colour code: $\mathrm{C}-\mathrm{H} \cdots \mathrm{N}$ purple), $\mathrm{C}-\mathrm{H} \cdots \mathrm{H}-\mathrm{C}$ (light blue), inversion centre (orange sphere), and incomplete contacts (red).

value of $2.80 \AA$ (= VDW + 0.40) discussed by Dance [17]. All three distance values must be treated with caution since their $\mathrm{H}$ atoms are in calculated positions. However, since these are well-defined Ar-H groups, their positional errors will be relatively small. Over recent years much understanding has been gained of dihydrogen bonding $\mathrm{X}-\mathrm{H} \cdots \mathrm{H}-\mathrm{Y}[18,19]$. Close examination has been made of the alkane $\mathrm{C}-\mathrm{H} \cdots \mathrm{H}-\mathrm{C}$ contact, particularly for reactive structures stabilised by multiple tert-butyl groups [20,21], multi-ring cage hydrocarbons [22,23], and linear alkanes $[22,23]$. The interaction was found to be attractive in all these cases, and computational justifications have been published $[21,23]$. It, therefore, appears probable that, despite their unfamiliarity, the $\mathrm{C}-\mathrm{H} \cdots \mathrm{H}-\mathrm{C}$ contacts illustrated in Figure 6 are similarly attractive in nature. 


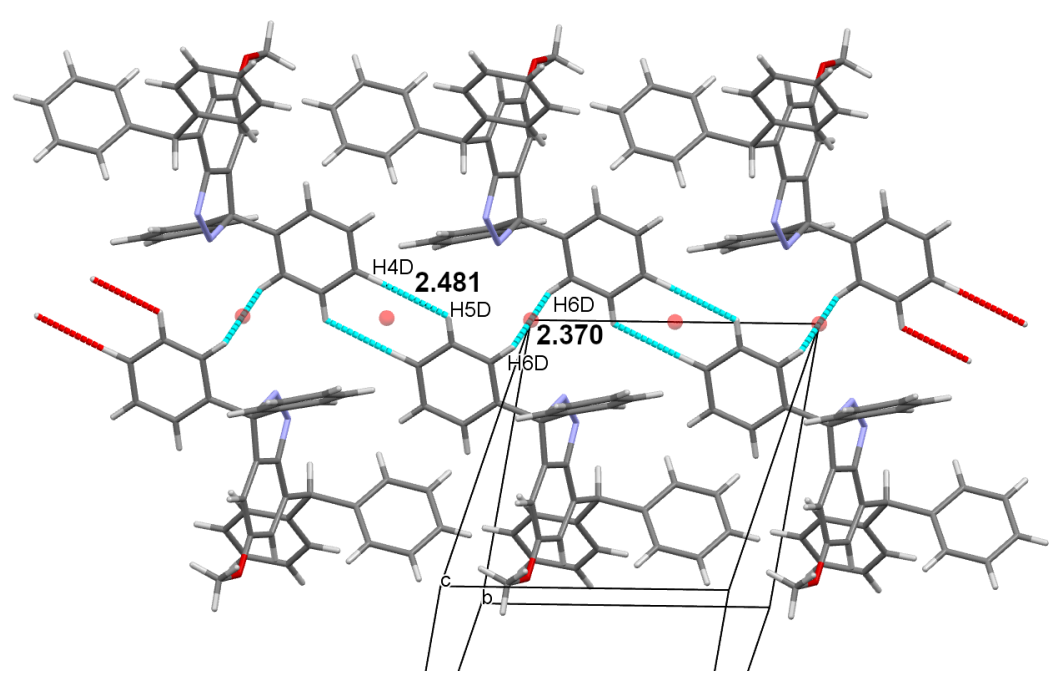

Figure 6: Part of a hydrocarbon tape along a formed by a combination of alternating linear and cyclic $\mathrm{C}-\mathrm{H} \cdots \mathrm{H}-\mathrm{C}$ close contacts. Crystallographic colour code: $\mathrm{C}-\mathrm{H} \cdots \mathrm{H}-\mathrm{C}$ (light blue), inversion centre (orange sphere), and incomplete contacts (red).

\section{Proposed mechanism for the formation of 8}

Indazoles are well-recognised for their important biological activities. They are known to be used as building blocks in drug development. A review by Gaikwad et al. describes reliable routes to particularly fused aromatic $1 \mathrm{H}$ and $3 H$-indazoles [24]. The common synthetic routes for the formation of cyclic $1 H$-indazoles are diazotisation of corresponding $o$-alkylanilines [25] and nitrosation of the $\mathrm{N}$-acetyl derivatives of 2-alkylanilines (Jacobson modification) [26-28]. More recently, the formation of cyclic 3,3-disubstituted $3 \mathrm{H}$-indazoles was reported to form mainly through the $[2+3]$ cycloaddition of diazo compounds with arynes under mild reaction conditions [29-31]. However, none of these contained a 2-diphenylmethyl (benzhydryl) aniline system, as found in our compound $\mathbf{5}$.

The formation of compound $\mathbf{8}$ can be explained by the rearrangement of $\mathbf{7}$ through a hydrogen-shift to form the diazo intermediate 9 which underwent a concerted [2+3] intramolecular cyclisation to 3,3-diphenyl-3H-indazole 8 (Scheme 2 ). The process was facilitated by the presence of a highly activated benzylic carbon and further expedited by three phenyl groups, to form the resonance stabilisation of 9 [32]. Furthermore, 8 cannot attain planarity of the methylene-benzhydryl fragment due to steric hindrance. These reactions appear to be also encouraged by the reduction of the crowding originally present in the diazonium salt.

The direct diazotisation of $\mathbf{5}$ was performed using anhydrous organic solvents and $t$-BuONO at $-10{ }^{\circ} \mathrm{C}$ in the presence of $\mathrm{CuCl}_{2}$ (method a) and the classical $\mathrm{NaNO}_{2} / \mathrm{HCl}$ method $\mathrm{b}$ in the absence of $\mathrm{CuCl}_{2}$, as shown in Scheme 3. Compound 8 was obtained in $89 \%$ and $96 \%$ from method a or b, respectively. The results confirm our initial hypothesis that the cyclisation occurred through the diazo species 9 (Scheme 2) and the $\mathrm{Cu}^{2+}$ plays no part in the reaction process.<smiles>COc1cc(C(c2ccccc2)c2ccccc2)c2c(c1)C(c1ccccc1)(c1ccccc1)N=N2</smiles>

Scheme 3: Direct preparation of compound 8. method a: $t$-BuONO, $\mathrm{CuCl}_{2}$, dry $\mathrm{CH}_{3} \mathrm{CN},-10{ }^{\circ} \mathrm{C}, 89 \%$; method b: $\mathrm{NaNO}_{2}, \mathrm{HCl} /$ acetic acid, $-10{ }^{\circ} \mathrm{C}, 96 \%$.<smiles>CN=Nc1c(C(c2ccccc2)c2ccccc2)cc(OC)cc1C(c1ccccc1)c1ccccc1</smiles><smiles>COc1cc2c(c(C(c3ccccc3)c3ccccc3)c1)CCOCCOCCC2c1ccccc1</smiles><smiles>COc1cc(C(c2ccccc2)c2ccccc2)c2c(c1)C(c1ccccc1)(c1ccccc1)N=N2</smiles>

Scheme 2: Proposed mechanism for the formation of 8 . 


\section{Conclusion}

The formation of the unexpected product $\mathbf{8}$ from $\mathbf{5}$ under anhydrous diazotisation conditions has led to the discovery of a facile synthetic pathway to 3,3-diphenyl-3H-indazoles. Formation of $\mathbf{8}$ has been proposed to proceed through the diazonium intermediate. This was further confirmed by reactions of $\mathbf{5}$ using $t$-BuONO, and the conventional $\mathrm{NaNO}_{2} / \mathrm{HCl}$ method to give $\mathbf{8}$ in almost quantitative yields. The crystal structure of $\mathbf{8}$ involves edge-face $\mathrm{Ar}-\mathrm{H} \cdots \pi$, face-face $\pi \cdots \pi$, bifurcated $\mathrm{OCH}_{2}-\mathrm{H} \cdots \mathrm{N}$, plus edge-edge centrosymmetric $\mathrm{Ar}-\mathrm{H} \cdots \mathrm{H}-\mathrm{Ar}$ interactions. These rather uncommon examples of dihydrogen contact assemble as infinite tapes along the $a$ direction.

\section{Experimental}

\section{Materials and physical measurements}

All chemical reagents and analytical grade solvents were obtained from commercial sources such as Sigma-Aldrich, Cambridge Isotope Laboratories Inc. and Merck Millipore. All reactions were monitored using either TLC aluminium oxide 60 F254 neutral or TLC Silica gel 60 F254 with UV detection at $254 \mathrm{~nm} .{ }^{1} \mathrm{H}$ NMR and ${ }^{13} \mathrm{C}$ NMR spectra were recorded on an Agilent $500 \mathrm{MHz}$ spectrometer $\left(500 \mathrm{MHz}{ }^{1} \mathrm{H}, 125 \mathrm{MHz}{ }^{13} \mathrm{C}\right)$ in deuterated chloroform $\left(\mathrm{CDCl}_{3}\right)$. The mass spectral data were obtained using the attached Agilent 5973n MS (EI) spectrometer. High-resolution mass spectra were obtained using an Agilent 6510 Q-TOF Mass Spectrometer (ESI). The infrared spectra were recorded on an Agilent Cary 630 FTIR with a diamond window using 16 background and sample scans. Melting points were measured on a Gallenkamp Melting Point Apparatus equipment and were uncorrected.

\section{Synthesis of 7-benzhydryl-5-methoxy-3,3- diphenyl-3H-indazole (8)}

2,6-Bis(diphenylmethyl)-4-methoxyaniline $(5,0.23 \mathrm{~g}$, 0.505 mmol, 1 equiv) DABSO ( $0.57 \mathrm{~g}, 2.37 \mathrm{mmol}, 4.75$ equiv) and BTEAC (0.12 g, $1 \mathrm{mmol}, 1$ equiv) were dissolved in DCM ( $5 \mathrm{~mL}$, solution A) that had been cooled to $0{ }^{\circ} \mathrm{C}$. tert-Butyl nitrite $(0.15 \mathrm{~g}, 170 \mu \mathrm{L})$ was dissolved in DCM $(6 \mathrm{~mL})$ and cooled to $0{ }^{\circ} \mathrm{C}$ (solution B). Copper(II) chloride $(0.02 \mathrm{~g}$, $0.10 \mathrm{mmol}, 0.1$ equiv) was dissolved in acetonitrile $(6 \mathrm{~mL})$ with sonication and cooled to $0{ }^{\circ} \mathrm{C}$ (solution $\mathrm{C}$ ). Once all solutions had been cooled the following order of addition was used: solution $\mathrm{C}$ was added to solution A dropwise. Solution $\mathrm{B}$ was added dropwise to solutions $\mathrm{A}$ and $\mathrm{C}$. The reaction was allowed to react at room temperature for $24 \mathrm{~h}$ before the organic product was extracted using DCM $(3 \times 10 \mathrm{~mL})$ and brine $(10 \mathrm{~mL})$. The organic layers were combined, dried over anhydrous sodium sulphate and the solvent was removed under reduced pressure. The solid crude product was crystallised from dichloromethane to give a brown crystalline solid $(0.064 \mathrm{~g}, 0.137 \mathrm{mmol}, 27 \%)$; $\mathrm{mp} 183-184{ }^{\circ} \mathrm{C}$; IR (neat) $v_{\max } / \mathrm{cm}^{-1}: 3057,3025,2959,2926$,
2650, 2322, 2112, 1943, 1591, 1490, 1470, 1445, 1349, 1263, 1205, 1127, 1023, 843, 748, 607; ${ }^{1} \mathrm{H}$ NMR (500 MHz, $\mathrm{CDCl}_{3}$ ) ठ 7.28-7.31 (m, H-Ar, 10H), 7.26-7.21 (m, H-Ar, 10H), 6.92 $(\mathrm{d}, J=2.0 \mathrm{~Hz}, \mathrm{H}-\mathrm{Ar}, 1 \mathrm{H}), 6.82\left(\mathrm{~s}, H \mathrm{C}(\mathrm{Ph})_{2}, 1 \mathrm{H}\right), 6.67(\mathrm{~d}, J=$ $2.0 \mathrm{~Hz}, \mathrm{H}-\mathrm{Ar}, 1 \mathrm{H}), 3.75$ (s, O-CH $\left.\mathrm{CH}_{\underline{3}}, 3 \mathrm{H}\right) ;{ }^{13} \mathrm{C} \mathrm{NMR}(125 \mathrm{MHz}$, $\mathrm{CDCl}_{3}$ ) $\delta 161.6(\mathrm{C}), 149.9$ (C), 146.6 (C), 142.9 (2C), 139.9 (C), $138.3(2 \mathrm{C}) 129.7(4 \mathrm{CH}), 128.6(4 \mathrm{CH}), 128.4(4 \mathrm{CH}), 128.0$ $(2 \mathrm{CH}), 127.8(4 \mathrm{CH}), 126.6(2 \mathrm{CH}), 115.9(\mathrm{CH}), 107.7(\mathrm{CH})$, $101.5\left(\mathrm{C}(\mathrm{Ph})_{2}\right), 55.8\left(\mathrm{CH}_{3}\right), 51.3\left(\mathrm{HC}(\mathrm{Ph})_{2}\right)$; HRMS-ESI $(\mathrm{m} / \mathrm{z})$ : $[\mathrm{M}+\mathrm{H}]^{+}$calcd for $\mathrm{C}_{33} \mathrm{H}_{27} \mathrm{~N}_{2} \mathrm{O}, 467.2118$; found, 467.2126.

\section{Direct preparation of compound 8 - method a}

Under a nitrogen atmosphere, compound 5 (0.23 g, $0.505 \mathrm{mmol}, 1$ equiv) was dissolved in acetonitrile $(20 \mathrm{~mL})$ then cooled to $0{ }^{\circ} \mathrm{C}$ (solution A). tert-Butyl nitrite $(0.15 \mathrm{~g}$, $170 \mu \mathrm{L})$ was dissolved in DCM $(6 \mathrm{~mL})$ and cooled to $0{ }^{\circ} \mathrm{C}$ (solution B). Copper(II) chloride $(0.02 \mathrm{~g}, 0.10 \mathrm{mmol}$, 0.2 equiv), was dissolved in acetonitrile $(6 \mathrm{~mL})$ with sonication and cooled to $0{ }^{\circ} \mathrm{C}$ (solution $\mathrm{C}$ ). Once all solutions had been cooled, the following order of addition was used: solution $\mathrm{C}$ was added to solution A dropwise. Solution B was added dropwise to solutions $\mathrm{A}$ and $\mathrm{C}$. The reaction was allowed to react at room temperature for $24 \mathrm{~h}$ before the organic product was extracted using DCM $(3 \times 10 \mathrm{~mL})$ and brine $(10 \mathrm{~mL})$. The organic layers were combined, dried over anhydrous sodium sulphate and the solvent was removed under reduced pressure to give the crude product which was purified by filtering through a short column flash silica gel using DCM as the mobile phase to give 8 (0.210 g, $0.449 \mathrm{mmol}, 89 \%)$.

\section{Direct preparation of compound 8 - method $b$}

Compound 5 (0.23 g, 0.505 mmol, 1 equiv) was dissolved in acetonitrile $(10 \mathrm{~mL})$ at room temperature before acetic acid (0.96 mL, $14.76 \mathrm{mmol}, 29$ equiv) and concentrated hydrochloric acid $(0.98 \mathrm{~mL}, 27 \mathrm{mmol}, 54$ equiv) was added dropwise to the solution over $2 \mathrm{~min}$ at $-10{ }^{\circ} \mathrm{C}$. Sodium nitrite $(0.123 \mathrm{~g}$, $1.72 \mathrm{mmol}, 3.4$ equiv) in water $(5 \mathrm{~mL})$ was added to the stirring solution over $1 \mathrm{~min}$ at $-10^{\circ} \mathrm{C}$. The resulting solution was stirred for $1 \mathrm{~h}$ at $-10{ }^{\circ} \mathrm{C}$ followed by $24 \mathrm{~h}$ at room temperature. The organic product was extracted using DCM $(3 \times 20 \mathrm{~mL})$ and brine $(30 \mathrm{~mL})$. The organic layers were combined, dried over anhydrous sodium sulphate and the solvent was removed under reduced pressure to give the pure product 8 (0.226 g, $0.485 \mathrm{mmol}, 96 \%$ ). The ${ }^{1} \mathrm{H}$ NMR spectrum of the crude product indicates that it is pure and required no further purification.

\section{X-ray crystallography}

A colourless plate-like crystal of $\mathbf{8}$ with dimensions of $0.11 \times 0.19 \times 0.22 \mathrm{~mm}$, selected under the polarising microscope (Leica M165Z), was mounted on a MicroMount 
(MiTeGen, USA) consisting of a thin polymer tip with a wicking aperture. The X-ray diffraction measurements were carried out on a Bruker kappa-II CCD diffractometer at $150 \mathrm{~K}$ using $\mathrm{I} \mu \mathrm{S}$ Incoatec Microfocus Source with Mo K $\alpha$ radiation $(\lambda=0.710723 \AA)$. The single crystal, mounted on the goniometer using a cryo-loop for intensity measurements, was coated with immersion oil type NVH and then quickly transferred to the cold nitrogen stream generated by an Oxford Cryostream 700 series. Symmetry-related absorption corrections using the program SADABS [33] were applied, and the data were corrected for Lorentz and polarisation effects using Bruker APEX3 software [33]. The structure was solved by program SHELXT [34] (with intrinsic phasing), and the fullmatrix least-square refinements were carried out using SHELXL-2014 [35] through Olex2 [36] suite of software. The non-hydrogen atoms were refined anisotropically. Molecular graphics were generated using Mercury [37]. Key crystallographic data and refinement details are presented in Table 1 .

\section{Crystal structure data}

Crystallographic data (excluding structure factors) for the structures in this paper have been deposited with the Cambridge Crystallographic Data Centre as supplementary publication number 1902859. The data can be obtained free of charge via http://www.ccdc.cam.ac.uk or by e-mailing data_request@ccdc.cam.ac.uk, or by contacting The Cambridge Crystallographic Data Centre, 12, Union Road, Cambridge CB2 1EZ, UK; fax: (+44) 1223/336-033, Tel.: (+44) 1223/336-408.

\section{Supporting Information}

\section{Supporting Information File 1 \\ Copies of ${ }^{1} \mathrm{H}$ NMR, ${ }^{13} \mathrm{C}$ NMR and IR of compound 8 . \\ [https://www.beilstein-journals.org/bjoc/content/ \\ supplementary/1860-5397-15-134-S1.pdf]}

\section{Acknowledgements}

We are grateful to the University of Technology Sydney for providing financial support to this project and Drs Maxine Roberts, Benjamin Fraser and Giancarlo Pascali at ANSTO for technical assistance and useful discussions. We also would like to thank the Australian Institute of Nuclear Science and Engineering (AINSE) for providing Andrew King with the AINSE Honours scholarship.

\section{ORCID ${ }^{\circledR}$ iDs}

Hugh G. Hiscocks - https://orcid.org/0000-0002-5587-8289 Lidia Matesic - https://orcid.org/0000-0001-8115-8325 Mohan Bhadbhade - https://orcid.org/0000-0003-3693-9063
Roger Bishop - https://orcid.org/0000-0002-6067-7289 Alison T. Ung - https://orcid.org/0000-0002-5665-0702

\section{References}

1. Brouwer, A. J.; Jonker, A.; Werkhoven, P.; Kuo, E.; Li, N.; Gallastegui, N.; Kemmink, J.; Florea, B. I.; Groll, M.; Overkleeft, H. S.; Liskamp, R. M. J. J. Med. Chem. 2012, 55, 10995-11003. doi:10.1021/jm301443r

2. Narayanan, A.; Jones, L. H. Chem. Sci. 2015, 6, 2650-2659. doi:10.1039/c5sc00408j

3. Grimster, N. P.; Connelly, S.; Baranczak, A.; Dong, J.; Krasnova, L. B.; Sharpless, K. B.; Powers, E. T.; Wilson, I. A.; Kelly, J. W. J. Am. Chem. Soc. 2013, 135, 5656-5668. doi:10.1021/ja311729d

4. Inkster, J. A. H.; Liu, K.; Ait-Mohand, S.; Schaffer, P.; Guérin, B.; Ruth, T. J.; Storr, T. Chem. - Eur. J. 2012, 18, 11079-11087. doi:10.1002/chem.201103450

5. Matesic, L.; Wyatt, N. A.; Fraser, B. H.; Roberts, M. P.; Pham, T. Q.; Greguric, I. J. Org. Chem. 2013, 78, 11262-11270. doi:10.1021/jo401759z

6. Smith, T. A. D. J. Labelled Compd. Radiopharm. 2012, 55, 281-288. doi:10.1002/jlcr.2940

7. Emmett, E. J.; Willis, M. C. Asian J. Org. Chem. 2015, 4, 602-611. doi:10.1002/ajoc.201500103

8. Woolven, H.; Gonzalez-Rodriguez, C.; Marco, I.; Thompson, A. L.; Willis, M. C. Org. Lett. 2011, 13, 4876-4878. doi:10.1021/ol201957n

9. Deeming, A. S.; Russell, C. J.; Hennessy, A. J.; Willis, M. C. Org. Lett. 2014, 16, 150-153. doi:10.1021/ol403122a

10. Hu, T.; Baxendale, I. R.; Baumann, M. Molecules 2016, 21, 918. doi:10.3390/molecules21070918

11. Meiries, S.; Speck, K.; Cordes, D. B.; Slawin, A. M. Z.; Nolan, S. P. Organometallics 2013, 32, 330-339. doi:10.1021/om3011867

12. Malet-Sanz, L.; Madrzak, J.; Ley, S. V.; Baxendale, I. R. Org. Biomol. Chem. 2010, 8, 5324-5332. doi:10.1039/c0ob00450b

13. Zhou, J.; Liu, L. L.; Cao, L. L.; Stephan, D. W. Angew. Chem., Int. Ed. 2018, 57, 3322-3326. doi:10.1002/anie.201713118

14. Desiraju, G. R.; Steiner, T. The Weak Hydrogen Bond: In Structure Chemistry and Biology; Oxford University Press: Oxford, United Kingdom, 1999.

15. Bhosekar, G.; Murali, C.; Gonnade, R. G.; Shashidhar, M. S.; Bhadbhade, M. M. Cryst. Growth Des. 2005, 5, 1977-1982. doi:10.1021/cg050272j

16. Bondi, A. J. Phys. Chem. 1964, 68, 441-451. doi:10.1021/j100785a001 17. Dance, I. New J. Chem. 2003, 27, 22-27. doi:10.1039/b206867b

18. Crabtree, R. H. Science 1998, 282, 2000-2001. doi:10.1126/science.282.5396.2000

19. Custelcean, R.; Jackson, J. E. Chem. Rev. 2001, 101, 1963-1980. doi:10.1021/cr000021b

20. Matta, C. F.; Hernández-Trujillo, J.; Tang, T.-H.; Bader, R. F. W. Chem. - Eur. J. 2003, 9, 1940-1951. doi:10.1002/chem.200204626

21. Wang, C.-C.; Tang, T.-H.; Wu, L.-C.; Wang, Y. Acta Crystallogr., Sect. A: Found. Crystallogr. 2004, 60, 488-493. doi:10.1107/s0108767304015375

22. Echeverría, J.; Aullón, G.; Danovich, D.; Shaik, S.; Alvarez, S. Nat. Chem. 2011, 3, 323-330. doi:10.1038/nchem.1004

23. Danovich, D.; Shaik, S.; Neese, F.; Echeverría, J.; Aullón, G.; Alvarez, S. J. Chem. Theory Comput. 2013, 9, 1977-1991. doi:10.1021/ct400070j 
24. Gaikwad, D. D.; Chapolikar, A. D.; Devkate, C. G.; Warad, K. D.; Tayade, A. P.; Pawar, R. P.; Domb, A. J. Eur. J. Med. Chem. 2015, 90, 707-731. doi:10.1016/j.ejmech.2014.11.029

25. Stadlbauer, W. Indazoles. In Science of Synthesis; Neier, R., Ed.; Georg-Thieme Verlag: Stuttgart, New York, 2002; Vol. 12, pp 227-324.

26. Jacobson, P.; Huber, L. Ber. Dtsch. Chem. Ges. 1908, 41, 660-671. doi:10.1002/cber.190804101127

27. Rüchardt, C.; Hassmann, V. Liebigs Ann. Chem. 1980, 908-927. doi:10.1002/jlac.198019800611

28. Yoshida, T.; Matsuura, N.; Yamamoto, K.; Doi, M.; Shimada, K.; Morie, T.; Kato, S. Heterocycles 1996, 43, 2701-2712. doi:10.3987/com-96-7614

29. Jin, T.; Yamamoto, Y. Angew. Chem., Int. Ed. 2007, 46, 3323-3325. doi:10.1002/anie.200700101

30. Liu, Z.; Shi, F.; Martinez, P. D. G.; Raminelli, C.; Larock, R. C. J. Org. Chem. 2008, 73, 219-226. doi:10.1021/jo702062n

31. Cheng, B.; Bao, B.; Zu, B.; Duan, X.; Duan, S.; Li, Y.; Zhai, H. RSC Adv. 2017, 7, 54087-54090. doi:10.1039/c7ra12117b

32. Shirtcliff, L. D.; Hayes, A. G.; Haley, M. M.; Köhler, F.; Hess, K.; Herges, R. J. Am. Chem. Soc. 2006, 128, 9711-9721. doi:10.1021/ja054547v

33. APEX3, SAINT and SADABS, Bruker 2016; Bruker AXS Inc.: Madison, Wisconsin, USA, 2016.

34. Sheldrick, G. M. Acta Crystallogr., Sect. A: Found. Adv. 2015, 71, 3-8. doi:10.1107/s2053273314026370

35. Sheldrick, G. M. Acta Crystallogr., Sect. C: Struct. Chem. 2015, 71 , 3-8. doi:10.1107/s2053229614024218

36. Dolomanov, O. V.; Bourhis, L. J.; Gildea, R. J.; Howard, J. A. K.; Puschmann, H. J. Appl. Crystallogr. 2009, 42, 339-341. doi:10.1107/s0021889808042726

37. Macrae, C. F.; Edgington, P. R.; McCabe, P.; Pidcock, E.; Shields, G. P.; Taylor, R.; Towler, M.; van de Streek, J. J. Appl. Crystallogr. 2006, 39, 453-457. doi:10.1107/s002188980600731x

\section{License and Terms}

This is an Open Access article under the terms of the Creative Commons Attribution License (http://creativecommons.org/licenses/by/4.0). Please note that the reuse, redistribution and reproduction in particular requires that the authors and source are credited.

The license is subject to the Beilstein Journal of Organic Chemistry terms and conditions:

(https://www.beilstein-journals.org/bjoc)

The definitive version of this article is the electronic one which can be found at: $\underline{\text { doi:10.3762/bjoc. } 15.134}$ 